\title{
Peran persepsi terhadap electronic service quality dan electronic word-of mouth (e-wom) terhadap intensi pembelian ulang melalui e-commerce
}

\author{
Dian Febriany Putri ${ }^{1}$ dan Sumaryono ${ }^{2}$
}

\begin{abstract}
Expanding the process of buying and selling goods or business transactions from offline to online becomes a challenge for its users. The intensity of purchasing goods by consumers through e-commerce is influenced by various factors, one of which is the perception of electronic service quality and electronic word-of-mouth (e-wom). The purpose of this study is to find out the role of perceptions of electronic service quality and electronic word-ofmouth (e-WOM) toward re-purchase intention through e-commerce. Respondents in this research were individuals with an age range of 18-35 years and the total of respondents were 232 people. The sampling technique used purposive sampling. Data was collected using the re-purchase intention, perception of electronic service quality and e-WOM scales. Methods of data analysis using Structural Equation Modeling (SEM). The results of the study explain that one's perception of electronic service quality and information circulating through e-WOM each have a role in influencing or strengthening consumer intentions to repurchase products through e-commerce.
\end{abstract}

\section{Keywords}

consumer behavior, perception, quality of service

\section{Pendahuluan}

Perkembangan teknologi informasi dan internet ternyata turut berdampak pada proses jual beli barang atau transaksi bisnis. Saat ini internet telah mengubah cara kerja bisnis, sehingga sangat memungkinkan bagi para retailers untuk menawarkan serangkaian produk dan layanan yang tidak terbatas pada semua konsumen dari seluruh dunia setiap saat (Lim et al., 2010). Apabila dahulu masyarakat sangat familier dengan metode jual beli secara konvensional, saat ini masyarakat mulai familier dengan transaksi jual beli secara daring yang memanfaatkan jaringan internet di dalam prosesnya atau e-commerce.

Saat ini banyak masyarakat yang beralih pada metode jual beli daring karena secara umum dinilai praktis dan cepat. Perkembangan teknologi informasi dan transportasi logistik menjadikan proses pembelian secara daring menjadi lebih mudah dan populer (Zheng et al., 2020). Sebelum penelitian ini dilakukan, peneliti melakukan preliminary study di mana pemerolehan data dilakukan dengan menggunakan metode wawancara personal dengan dua responden yang telah beberapa kali memiliki pengalaman dalam berbelanja secara daring. Berdasarkan hasil wawancara, diperoleh bahwa faktor kemudahan, efisiensi dan variasi pilihan barang maupun alternatif transaksi pembayaran menjadi beberapa hal yang memengaruhi responden dalam pembelian barang secara daring. Kemudahan dan efisiensi yang dimaksudkan antara lain seperti responden tidak perlu menghabiskan waktu untuk berpindah dari satu tempat ke tempat lainnya secara fisik hanya sekedar untuk mencari suatu barang atau membandingkan harga. Selain itu, kemudahan dan variasi dalam proses pembayaran juga dapat dikatakan hampir sama ketika melakukan pembelian secara luring, di mana salah satunya adalah dengan pemanfaatan kartu kredit. Hasil preliminary study ini pun didukung oleh (Mittal \& Jhamb, 2016) yang mengungkapkan bahwa terdapat empat dimensi utama yang menjadi penentu daya tarik sebuah tempat untuk berbelanja, antara lain: 1) merchandising, 2) variasi dan pilihan, 3) lingkungan dan fasilitas, serta 4) kenyamanan.

Akan tetapi, menjamurnya usaha berbasis daring saat ini membuat konsumen sendiri harus jeli di dalam memilih usaha manakah yang kompeten dan terpercaya. Salah satu cara yang dapat dilakukan untuk menilai bahwa usaha atau barang yang akan dipilih dalam suatu usaha berbasis daring memiliki reputasi yang baik adalah dengan melihat ulasan

\footnotetext{
${ }^{1}$ Fakultas Psikologi dan IImu Sosial Budaya Universitas Islam Indonesia ${ }^{2}$ Fakultas Psikologi Universitas Gadjah Mada

Korespondensi:

Dian Febriany Putri, Fakultas Psikologi dan IImu Sosial Budaya Universitas Islam Indonesia, Jalan Kaliurang KM. 14,5 Sleman, Yogyakarta, 55584

Email: dian.febriany.putri@uii.ac.id
} 
dari konsumen terhadap usaha atau barang tersebut pada bagian testimoni.

Meski demikian, hingga saat ini masih sering ditemukan komplain yang diungkapkan konsumen. Kerap terdengarnya kasus penipuan yang mengatas namakan transaksi perdagangan secara daring juga semakin membuat masyarakat masih merasa takut untuk membeli barang dengan cara tersebut dan secara tidak langsung rasa percaya dari masyarakat pun cenderung tereduksi. Situasi ini salah satunya juga diungkapkan oleh Dhanapal et al. (2015) melalui penelitiannya bahwa risiko terhadap transaksi kartu kredit masih menjadi kendala yang paling signifikan untuk berbelanja daring ditinjau dari seluruh kelompok generasi, baik baby boomers, gen $\mathrm{X}$ maupun gen Y di Malaysia.

Hal terkait kepercayaan inilah yang sampai saat ini masih menjadi tantangan bagi para pelaku usaha daring. Para pelaku usaha daring harus bersaing menjawab keraguan masyarakat. Salah satu strategi yang dapat dilakukan oleh para pelaku usaha daring adalah dengan memberikan kualitas pelayanan prima kepada konsumen. Kualitas pelayanan yang diterima oleh konsumen menjadi salah satu kunci dari ukuran kepuasan konsumen, dan kepuasan konsumen ini merupakan isu kritis dari kesuksesan sistem bisnis, baik yang bersifat tradisional maupun daring (Sudirman et al., 2018). Adapun beberapa bentuk pelayanan prima dalam konteks daring antara lain adalah dengan memberikan tampilan desain yang menarik dan informatif pada web site, adanya jaminan keamanan, serta melakukan pengiriman pesanan secara cepat dan tepat (fulfilment) (Rita et al., 2019).

Pada sisi lain, para pelaku usaha daring saat ini tentunya membutuhkan keterikatan dari konsumen untuk dapat menjaga eksistensinya di tengah arus persaingan. Para pelaku usaha daring membutuhkan konsumen untuk dapat loyal, khususnya terhadap produk yang ditawarkan. Maka dari itu, para pelaku usaha daring ini perlu menciptakan citra yang baik dan mengomunikasikannya kepada target konsumen, agar konsumen memiliki nilai atau pandangan yang baik terhadap produk maupun merek terkait. Salah satu sumber informasi atau penguatan yang saat ini turut menjadi pertimbangan seseorang dalam melakukan pengambilan keputusan, salah satunya dalam hal transaksi pembelian, ialah berupa rekomendasi atau pengalaman orang lain yang tertuang dalam suatu testimoni pada forum atau situs ulasan daring (Palese \& Usai, 2018).

Pada pembelian yang dilakukan secara daring, awalnya konsumen akan mengevaluasi pelayanan yang diterima berdasarkan persepsinya terlebih dahulu. Adanya persepsi yang baik oleh konsumen terhadap pelayanan, dapat menimbulkan kepuasan pada konsumen. Adanya kepuasan dalam diri konsumen ini juga akan memunculkan pemikiran, penilaian dan sikap positif dari konsumen atas proses pembelian yang telah dilaluinya (Rizqulloh \& Elida, 2015). Hal inilah yang kemudian akan menjadi faktor yang memunculkan penguatan pada diri konsumen dengan cara memengaruhi keyakinan konsumen, terutama keyakinan yang bersifat personal dan berasal dari dalam atau internal diri individu. Keyakinan bahwa keseluruhan pelayanan yang diterima merupakan pelayanan yang baik, dapat berpotensi untuk memunculkan intensi pembelian ulang atas produk maupun usaha berbasis daring yang sama di masa mendatang. Hal ini senada oleh (Setyaningsih, 2014) di mana kualitas pelayanan berpengaruh dalam meningkatkan kepuasan dan kepercayaan konsumen terhadap produk. Kepuasan dan kepercayaan konsumen pada akhirnya berpengaruh terhadap loyalitas konsumen dalam mengonsumsi suatu produk. Pada hal lain, kualitas layanan, kualitas produk, nilai yang dirasakan dan harga menjadi faktor yang cukup baik dalam memengaruhi minat pembelian ulang konsumen (Putri, 2016).

Selain itu, konsumen juga membutuhkan sumber informasi tambahan dan penguatan tidak hanya untuk pembelian barang pertamanya, namun juga untuk semakin menguatkan intensi dalam pembelian ulang atas barang atau pada usaha berbasis daring yang sama. Salah satu sumber informasi tambahan tersebut dapat berupa ulasan atau komentar dari konsumen lain yang telah memiliki pengalaman dalam membeli atau mengonsumsi produk terkait. Adapun bentuk ulasan atau komentar yang berpengaruh antara lain adalah ulasan yang bernilai positif, penilaian dalam bentuk deskriptif, ulasan dalam bentuk gambar, ulasan tambahan, maupun ulasan yang sifatnya kumulatif (Mo et al., 2015). Hal tersebut dikarenakan adanya ulasan atau komentar yang bersifat positif merupakan indikator adanya kepuasan dari konsumen atas proses pembelian yang telah dilakukannya.

Kepuasan dalam diri konsumen tersebut kemudian menimbulkan pemikiran, penilaian dan sikap positif konsumen atas proses pembelian yang dialami. Pemikiran, penilaian dan sikap positif tersebut kemudian dapat diwujudkan dalam perilaku memberikan ulasan positif atau rekomendasi terkait produk atau usaha berbasis daring tempat pembelian dilakukan. Beredarnya ulasan maupun rekomendasi ini akan menjadi faktor yang memunculkan penguatan pada diri konsumen dengan cara memengaruhi keyakinannya, khususnya keyakinan yang merefleksikan pengaruh sosial dan bersumber dari luar atau eksternal individu. Adanya pengaruh sosial yang dirasakan konsumen berupa ulasan positif maupun rekomendasi tersebut dapat berpotensi untuk memunculkan intensi pembelian ulang atas produk maupun usaha berbasis daring yang sama di masa mendatang. Senada dengan hal tersebut, Constantinides \& Holleschovsky (2016) turut mengungkapkan bahwa ulasan konsumen dalam portal daring, adanya rekomendasi produk maupun layanan, serta opini sejawat memiliki peran yang besar dalam pengambilan keputusan konsumen.

Ulasan atau komentar positif ini tentunya juga akan memberikan keuntungan tidak hanya kepada calon konsumen yang akan melakukan pembelian, namun juga memberikan dampak yang menguntungkan bagi pelaku usaha 
daring bersangkutan karena pengaruhnya terhadap keputusan pembelian konsumen. Hal ini juga didukung salah satunya oleh Rembon et al. (2017) dalam penelitiannya yang menunjukkan bahwa informasi yang beredar di masyarakat dari satu orang kepada orang lainnya berpengaruh positif dan signifikan terhadap keputusan pembelian suatu produk. Adanya pemberian komentar maupun rekomendasi yang berulang-ulang tersebut mengembangkan fenomena komunikasi pemasaran, yaitu Word of Mouth (WOM). Sejalan dengan perkembangan teknologi, aktivitas WOM sendiri memiliki beberapa istilah baru yaitu electronic wordof mouth (e-WOM). Aktivitas WOM yang berlangsung melalui teks berupa pesan elektronik (Goyette et al., 2010).

Ajzen (2005) menyatakan bahwa niat atau intensi merupakan kecenderungan individu untuk menghubungkan diri dengan kemungkinan-kemungkinan serta tindakan mendatang. Adapun yang dimaksud dengan intensi pembelian ulang adalah kecenderungan individu atas respon terhadap suatu objek. Ketika seorang konsumen memperoleh respon positif atas tindakan masa lalu, hal tersebut akan memunculkan pemikiran positif dari diri konsumen dan akan terjadi penguatan. Adanya penguatan ini akan berpotensi atau memungkinkan individu untuk melakukan pembelian secara berulang.

Berdasar fenomena yang telah dijelaskan di atas, intensi pembelian ulang juga dapat dirasakan dalam konteks perdagangan daring asalkan konsumen yang melakukannya sudah familier dan mampu menggunakan teknologi sebagai media aktivitas pembelian daring. Selain itu, intensi pembelian ulang melalui e-commerce dapat diartikan juga sebagai kecenderungan perilaku membeli dari konsumen pada suatu produk barang dan jasa yang dilakukan secara berulang dalam jangka waktu tertentu dan secara aktif menyukai serta mempunyai sikap positif terhadap suatu produk barang atau jasa.Pembelian ulang melalui e-commerce memanfaatkan penggunaan teknologi informasi internet, sehingga tidak terdapat pertemuan dan interaksi secara fisik (Suryana \& Dasuki, 2013).

Akan tetapi pada kenyataannya, intensi merupakan hal yang berada pada area kognitif seseorang yang bersifat dinamis dan dapat berubah-ubah sepanjang waktu. Semakin lama tenggang waktu pengaruh diberikan, maka semakin banyak lingkungan yang sulit diantisipasi dan pada akhirnya dapat merubah keinginan itu sendiri. Kejadian dan lingkungan yang sulit diantisipasipun dapat terjadi dalam periode waktu yang relatif singkat karena banyak hal yang dapat merubah kepercayaan, sikap, keinginan dan perilaku konsumen (Peter\& Olson, 2013).

Penggunaan variabel intensi pembelian ulang sendiri memang telah banyak digunakan sebagai variabel dependen pada beberapa penelitian. Akan tetapi, penggunaan variabel tersebut secara khusus telah difokuskan sebelumnya pada sebuah toko daring maupun produk tertentu. Penggunaan variabel persepsi terhadap kualitas pelayanan dan WOM juga telah kerap digunakan sebagai variabel independen pada beberapa penelitian. Akan tetapi, penggunaan kedua variabel tersebut masih jarang yang berfokus pada konteks daring, melainkan lebih kepada konteks luring. Penggunaan variabel persepsi terhadap electronic service quality dan e-WOM pun masih tergolong jarang apabila secara langsung dihubungkan dengan intensi pembelian ulang. Berdasarkan hal tersebut, penelitian ini ingin mengetahui bagaimana intensi pembelian ulang melalui ecommerce ditinjau dari persepsi terhadap electronic service quality dan e-WOM.

Lebih lanjut, adapun tujuan dari penelitian ini adalah untuk mengetahui peran persepsi terhadap electronic service quality dan e-WOM terhadap intensi pembelian ulang melalui e-commerce. Manfaat teoritis yang dapat diperoleh adalah untuk pengembangan studi pada bidang Psikologi Konsumen, khususnya consumer behavior. Manfaat praktis yang dapat diperoleh dengan adanya penelitian ini antara lain dapat menjembatani antara penggiat usaha berbasis daring terhadap konsumen dengan cara memberi pemahaman mengenai keinginan, kebutuhan maupun ekspektasi pasar dari para konsumen berkaitan dengan variabel dalam penelitian ini. Mempertimbangkan variabel-variabel dalam penelitian ini, dapat menstimulasi para penggiat usaha berbasis daring dalam membidik pasar dan memunculkan langkah strategis baru agar dapat mempromosikan produknya ke pasaran secara lebih efektif.

\section{Metode}

\section{Subjek}

Penelitian ini menggunakan pendekatan kuantitatif survei. Subjek pada penelitian ini sejumlah 232 responden. Teknik purposive sampling digunakan sebagai teknik pengambilan data. Subjek dalam penelitian ini adalah (1) Pria maupun wanita dengan rentang usia 18-35 tahun, di mana subjek pada rentang usia yang familier terhadap e-commerce, familier menggunakan internet untuk mencari informasi, dan juga mampu memproses informasi melalui web site lima kali lebih cepat dibanding individu dengan usia di atasnya (Muda et al., 2016); dan (2) Konsumen yang sebelumnya pernah memiliki pengalaman melakukan aktivitas pembelian produk berbasis $e$-commerce lebih dari dua kali dalam kurun waktu satu tahun terakhir, agar subjek masih mudah untuk membayangkan dan mengingat kembali proses yang telah dialaminya.

\section{Variabel dan Instrumen}

Pada penelitian ini terdapat tiga variabel yang diteliti, yaitu: Intensi pembelian ulang melalui e-commerce sebagai variabel dependen, persepsi terhadap electronic service quality dan electronic word-of-mouth merupakan variabel independen. Persepsi terhadap electronic service quality adalah evaluasi keseluruhan konsumen terkait proses pembelian atau berbelanja secara daring dengan memanfaatkan fasilitas situs web secara efektif dan efisien (Lee \& Lin, 2005). Sementara itu, electronic word-ofmouth (e-WOM) didefinisikan sebagai komunikasi daring 
yang bersifat informal dan menyebar secara cepat antar individu yang terkait dengan suatu produk atau jasa (Goyette et al., 2010).

Ada tiga instrumen yang digunakan, yaitu: Skala Intensi Pembelian Ulang Melalui E-commerce, Skala Persepsi Terhadap Electronice Service Quality, dan Skala Electronic Word-of-Mouth (e-WOM).

Skala Intensi Pembelian Ulang Melalui E-Commerce. Skala disusun oleh peneliti dengan berdasar pada theory of planned behavior dari (Ajzen, 2005) dan mengacu pada penelitian (Grewal et al., 1998) serta (Dodds et al., 1991). Skala ini terdiri atas 24 aitem dengan koefisien reliabilitas sebesar $\alpha=0.96$; angka validitas bergerak dari 0.33 sampai 0.87 dan menggunakan jawaban skala Semantic Differential dengan menampilkan lima alternatif jawaban (1 = ragu hingga 5 = yakin).

Skala Persepsi Terhadap Electronic Service Quality. Skala disusun dengan mengacu pada penelitian (Lee \& Lin, 2005). Skala ini terdiri dari 22 aitem dengan koefisien reliabilitas sebesar $\alpha=0.88$; angka validitas bergerak dari 0.35 sampai 0.64 dan menggunakan jawaban skala Likert dengan menampilkan lima alternatif jawaban $(1$ = sangat tidak sesuai hingga 5= sangat sesuai).

Skala Electronic Word-of-Mouth (e-WOM). Skala disusun dengan mengacu pada penelitian (Goyette et al., 2010). Skala ini terdiri atas 17 aitem dengan koefisien reliabilitas sebesar $\alpha=0.88$; angka validitas bergerak dari 0.37 - 0.77 dan menggunakan jawaban skala Likert dengan menampilkan lima alternatif jawaban $(1=$ sangat tidak sesuai hingga $5=$ sangat sesuai).

\section{Analisis Data}

Metode analisis data dilakukan dengan menggunakan Structural Equation Modeling (SEM) dengan bantuan program AMOS 22.0. Analisis SEM merupakan analisis multivariat yang bersifat kompleks, karena melibatkan sejumlah variabel independen dan dependen yang saling berhubungan membentuk model (Santoso, 2010). Metode SEM sendiri lebih bersifat confirmatory, karena pembuat model atau peneliti diharuskan untuk membuat model yang menggambarkan pengaruh tidak langsung dari satu variabel ke variabel lainnya yang ditunjukkan dengan tanda panah pada diagram jalur (Golob, 2003).

\section{Hasil}

Sesuai dengan model yang dikembangkan pada penelitian ini, urutan langkah-langkah analisis mengacu pada proses analisis SEM dari (Ghozali, 2017). Pertama, adalah pengembangan model berdasar teori. Secara umum, model tersebut terdiri dari dua variabel independen (eksogen) yaitu, persepsi terhadap electronic service quality dan electronic word-of-mouth (e-WOM) dan satu variabel dependen (endogen) yaitu intensi pembelian ulang melalui e-commerce. Kedua, menyusun diagram jalur. Ketiga, konversi diagram jalur ke dalam persamaan
Tabel 1. Hasil Goodness-of-Fit

\begin{tabular}{lcrl}
\hline Goodness-of-Fit Index & Titik potong & Hasil & \\
\hline Chi-Square & Diharapkan kecil & 65.68 & Fit \\
CMIN/DF & $\leq 2.0$ & 1.29 & Fit \\
RMSEA & $\leq 0.08$ & 0.04 & Fit \\
\hline
\end{tabular}

Tabel 2. Tabel regression weights.

\begin{tabular}{lccc}
\hline Variabel & Estimasi & SE & Nilai krtis \\
\hline Intensi $\leftarrow$ Persepsi & 0.66 & 0.08 & $8.17^{\star \star *}$ \\
Intensi $\leftarrow$ EWOM & 0.70 & 0.06 & $11.88^{\star * *}$ \\
Intensi $\leftarrow$ Persepsi & 0.34 & & \\
Intensi $\leftarrow$ EWOM & 0.60 & & \\
\hline
\end{tabular}

Catatan: ${ }^{* * *} p<0.001$

struktural (lihat Gambar 1). Keempat, memilih jenis input matriks dan estimasi model yang diusulkan. Jenis input matriks yang digunakan adalah kovarian untuk menguji teori dan korelasi untuk melihat pola hubungan. Jenis estimasi model yang digunakan adalah estimasi Maximum Likelihood (ML). Kelima, menilai kriteria goodness-of-fit (lihat Tabel 1).

Berdasarkan Tabel 1, seluruh goodness-of-fit index menunjukkan hasil evaluasi fit. Artinya, model memang dapat dikatakan fit atau menunjukkan bahwa data empiris yang diperoleh pada penelitian sesuai dengan model teoritik yang dibangun. Lalu keenam, interpretasi estimasi model. Berikut ini merupakan output dari persamaan struktural setelah dijalankan:

Berdasarkan (Gambar 2), dapat dilihat bahwa nilai korelasi antara variabel independen penelitian yaitu variabel persepsi terhadap electronic service quality dan electronic word-of-mouth(e-WOM) adalah sebesar 0.82 yang menunjukkan bahwa hubungan di antara kedua variabel tersebut kuat. Jadi, dapat dikatakan bahwa terdapat hubungan positif antara variabel independen persepsi terhadap electronic service quality dan electronic wordof-mouth (e-WOM), sehingga dapat disimpulkan bahwa hipotesis ditolak. Variabel independen persepsi terhadap electronic service quality dan electronic word-of-mouth (e-WOM) masing-masing tidak mampu berdiri sendiri sebagai variabel prediktor untuk variabel intensi pembelian ulang melalui e-commerce karena memiliki korelasi satu sama lain.

Tabel 2 regression weights memberikan besarnya nilai koefisien regresi unstandardized dan standardized. Nilai kritis adalah sama dengan nilai t dan $p<0.001$. Maka disimpulkan bahwa persepsi terhadap electronic service quality berperan positif terhadap intensi pembelian ulang melalui e-commerce dengan koefisien standardized sebesar $0.396, p=0.000$, yang berarti persepsi seseorang atas electronic service quality memiliki peran dalam memengaruhi atau menguatkan intensi konsumen untuk melakukan pembelian ulang melalui e-commerce. Kemudian electronic word-of-mouth (e-WOM) juga berperan positif terhadap 


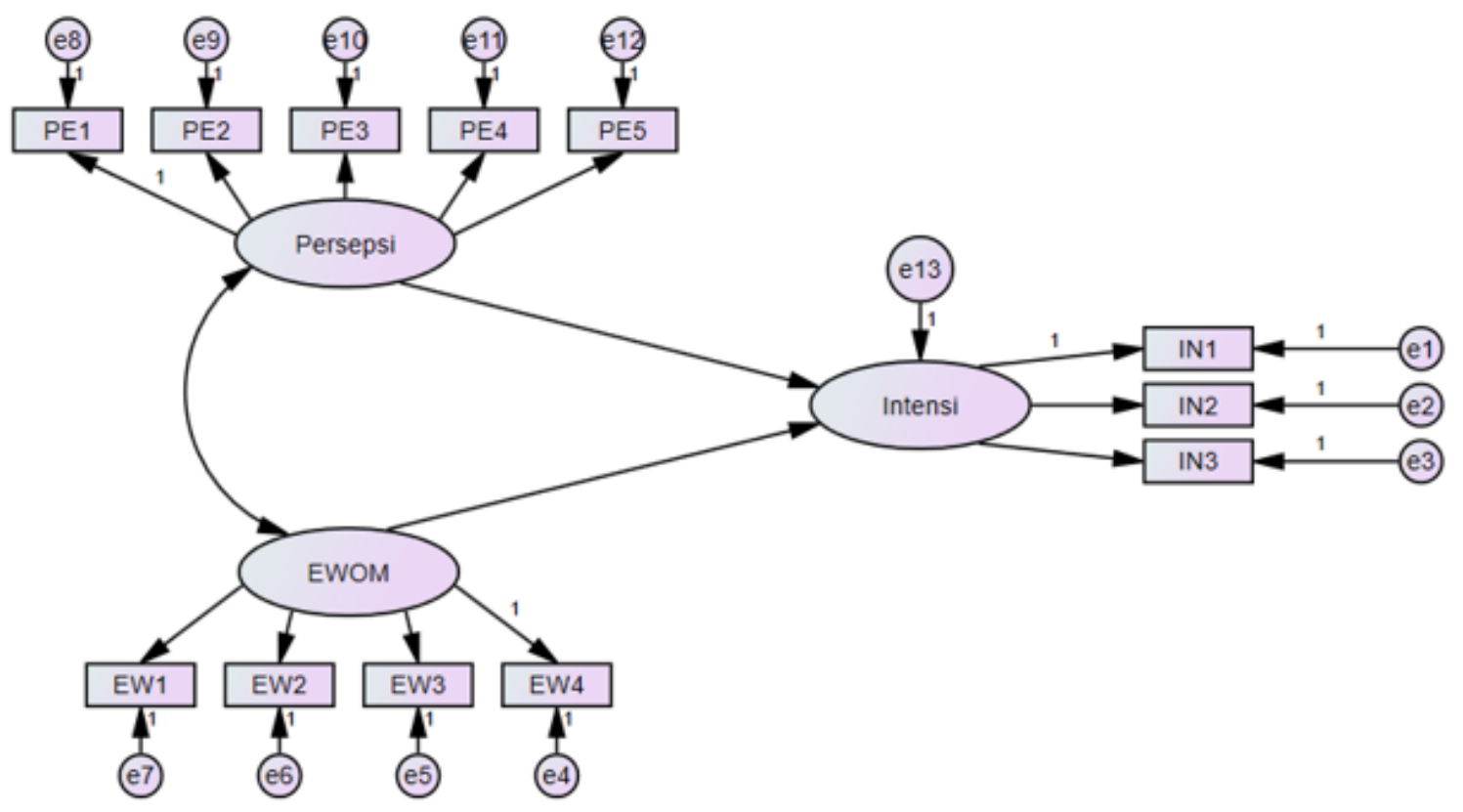

Gambar 1. Persamaan truktural antar variabel

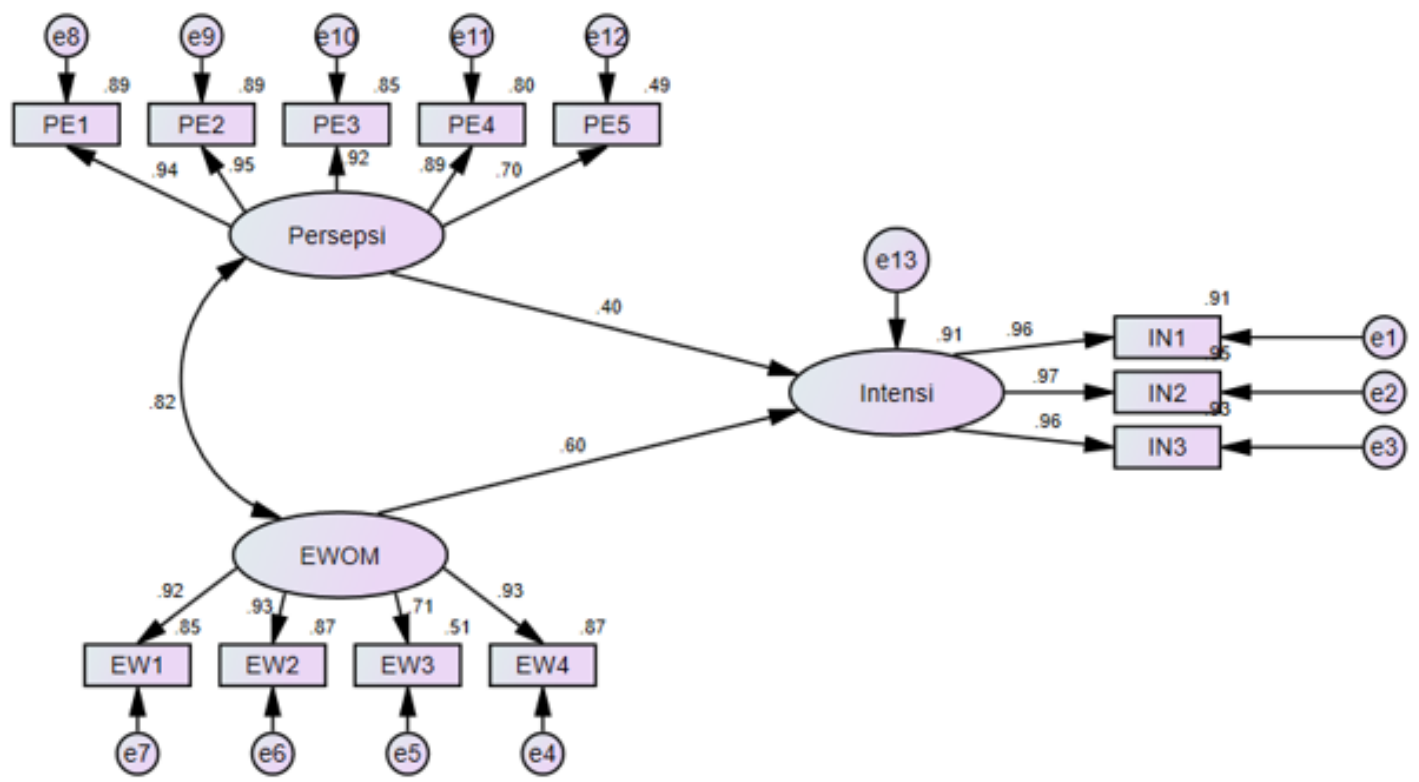

Gambar 2. Output persamaan struktural Antar variabel

intensi pembelian ulang melalui e-commerce dengan koefisien standardized sebesar 0.601 dan signifikan pada $\mathrm{p}$ value 0.000 , yang berarti informasi-informasi yang beredar melalui e-WOM turut berperan dalam memengaruhi atau menguatkan intensi konsumen dalam melakukan pembelian ulang suatu produk melalui e-commerce. Maka dapat disimpulkan bahwa hipotesis diterima yang berarti variabel persepsi terhadap electronic service quality berperan terhadap intensi pembelian ulang melalui e-commerce, begitu juga dengan variabel electronic word-of-mouth (eWOM) yang juga berperan terhadap intensi pembelian ulang melalui e-commerce.

\section{Pembahasan}

Temuan yang ditunjukkan berdasarkan hasil analisis di atas, diketahui bahwa persepsi terhadap electronic service quality dan e-WOM masing-masing berperan terhadap intensi pembelian ulang melalui $e$-commerce. Hal ini 
sesuai dengan yang diungkapkan oleh Putri (2016) bahwa kualitas pelayanan, kualitas produk, perceived value dan harga mampu memengaruhi minat beli ulang produk secara daring dengan cukup baik. Kualitas pelayanan berpengaruh dalam meningkatkan kepuasan dan kepercayaan konsumen terhadap produk. Kepuasan dan kepercayaan konsumen inilah yang kemudian pada akhirnya juga memiliki pengaruh terhadap loyalitas konsumen untuk mengonsumsi suatu produk (Setyaningsih, 2014), dan memunculkan pemikiran, penilaian serta sikap positif atas proses pembelian yang sebelumnya telah dilakukan (Rizqulloh \& Elida, 2015). Hal tersebut kemudian dapat memunculkan penguatan dan keyakinan pada diri konsumen bahwa kualitas pelayanan yang telah diterimanya adalah baik, sehingga dengan adanya keyakinan tersebut mampu memunculkan potensi untuk melakukan pembelian berulang di masa mendatang.

Begitu pula dengan penelitian yang dilakukan oleh Xiaofen \& Yiling (2009) yang menyatakan bahwa kesan dari WOM secara daring dan opinion leader berpengaruh positif terhadap intensi konsumen dalam membeli pakaian. Electronic word-of-mouth (e-WOM)dipandang mampu berperan terhadap intensi pembelian ulang karena adanya hal tersebut mengindikasikan adanya kepuasan dari para konsumen sebelumnya. Adanya kepuasan dalam diri konsumen yang pernah melakukan pembelian atas barang serupa sebelumnya mampu memunculkan pemikiran, penilaian dan sikap positif atas proses pembelian yang sebelumnya telah dilakukan (Rizqulloh \& Elida, 2015), serta memunculkan kepercayaan. Kepuasan dan kepercayaan inilah yang mampu mendorong seseorang untuk menyebarkan positive electronic word-of-mouth (eWOM). Namun, jika konsumen tidak merasa puas terhadap kinerja, barang, ataupun jasa yang ditawarkan sebelumnya, maka akan menimbulkan penilaian yang berkebalikan (Joesyiana, 2018). Selanjutnya, ulasan positif tersebut mampu memunculkan penguatan pada orang lain yang membacanya bahwa terdapat indikasi yang baik, baik dari segi usaha berbasis daring yang bersangkutan, produk yang ditawarkan, dan hal-hal lainnya. Adanya keyakinan tersebut kemudian mampu memunculkan potensi kembali untuk melakukan pembelian berulang di masa mendatang karena konsumen memperoleh penguatan kembali yang berasal dari sumber eksternal dirinya dan mengembangkan kembali seperangkat kepercayaan terkait produk yang sudah pernah digunakan sebelumnya (Febriani et al., 2011).

Hasil dari penelitian ini juga turut mendukung model penelitian yang dikemukakan dan dikembangkan oleh Ajzen (2005) mengenai Theory of Planned Behavior (TPB). TPB ini sendiri menjelaskan bahwa terdapat tiga determinan dari intensi, yaitu attitude toward the behavior, subjective norm dan perceived behavioral control yang mana ketiganya dibentuk oleh belief pada masing-masing determinan. Determinan attitude toward the behavior berasal dari evaluasi seseorang terhadap hasil yang akan diperoleh yang diasosiasikan dengan perilaku dan kekuatan asosiasi tersebut. Maka dapat dikatakan bahwa keyakinan ini bersumber dari dalam atau internal diri individu tersebut, seperti salah satunya adalah persepsi.

Kemudian determinan subjective norm dapat dikatakan sebagai seorang individu yang mempercayai orang lain atau kelompok referensinya yang menganggap suatu perilaku layak untuk dilakukan, maka individu tersebut akan merasakan tekanan sosial yang mendorongnya untuk berpikir dan melakukan perilaku tersebut. Maka dapat dikatakan bahwa keyakinan ini bersumber dari luar atau eksternal diri individu tersebut, seperti salah satunya adalah informasi-informasi dari media elektronik. Ajzen (2005) juga menjelaskan bahwa determinan tersebut dibentuk oleh belief pada masing-masing determinan.

Pada sisi lain, penelitian ini juga menunjukkan bahwa di antara persepsi terhadap electronic service quality dan electronic word-of-mouth (e-WOM), electronic word-ofmouth (e-WOM) lah yang lebih mampu menunjukkan peran lebih besar untuk memprediksi intensi pembelian ulang. Hal tersebut dikarenakan dalam konteks pemasaran saat ini seorang pelaku bisnis juga perlu untuk mengomunikasikan produknya kepada para calon konsumen melalui media dalam bentuk impersonal (media massa) atau interpersonal (percakapan formal antara penjual dan konsumen maupun percakapan informal antara dua orang atau lebih pada saat tatap muka, melalui telepon, pos, internet ataupun komunikasi WOM) Prasetijo \& Ihalauw (2005).

Konsumen biasanya menerima lebih banyak informasi dari sumber komersial dibandingkan dari sumber-sumber pribadi (Febriani et al., 2011). Salah satu yang termasuk dalam sumber komersial adalah program periklanan, di mana hal ini memiliki pengaruh besar terhadap pemrosesan informasi konsumen. Kemudian pemrosesan informasi sendiri pada akhirnya turut memiliki pengaruh langsung terhadap keputusan pembelian konsumen (Mujiyana \& Elissa, 2013). Hal tersebut menunjukkan bahwa pengaruh WOM, termasuk dalam konteks elektronik, begitu penting dalam memengaruhi pembelian, termasuk dalam pembelian ulang. Hal tersebut dikarenakan ketika seseorang sebelumnya sudah pernah menggunakan atau mengonsumsi suatu produk, untuk penggunaan selanjutnya juga turut diperlukan penguatan dari eksternal atau dari orang lain, terutama apabila terdapat kesan dan pengalaman kurang menyenangkan selama menggunakan produk. Konsumen dapat melakukan pencarian kembali mengenai bagaimana produk tersebut bekerja di orang lain. Apabila orang lain memiliki kesan dan pengalaman yang berbeda dengan dirinya yang mengindikasikan adanya pengalaman positif, maka memungkinkan bagi konsumen untuk mengembangkan kembali seperangkat kepercayaan terkait produk yang pernah digunakan sebelumnya (Febriani et al., 2011). Konsumen yang meyakini nilai WOM positif, maka akan meningkatkan kepercayaannya terhadap produk. Apabila kepercayaan konsumen terhadap produk tinggi, maka intensi konsumen untuk melakukan 
pembelian ulang pada suatu produk akan muncul, begitu pula sebaliknya.

Maka dari itu, penelitian ini sendiri sekaligus juga menunjukkan bahwa setiap usaha berbasis e-commerce saat ini harus memiliki strategi tertentu untuk melawan atau bertahan dalam arus persaingan guna mempertahankan eksistensi. Strategi yang direncanakan oleh para pelaku usaha berbasis e-commerce saat ini antara lain adalah para pelaku usaha harus turut mempertimbangkan dan melibatkan unsur kualitas pelayanan karena kualitas pelayanan yang baik dari sebuah usaha, khususnya usaha berbasis e-commerce, mampu menjadi salah satu hal yang menjadikan citra usaha menjadi baik. Selain itu, kualitas pelayanan dapat turut meningkatkan kepuasan serta kepercayaan konsumen terhadap suatu produk. Konsumen yang merasa puas dan telah memiliki kepercayaan, maka akan cenderung loyal untuk mengonsumsi suatu produk tertentu (Setyaningsih, 2014). Pada sisi lain, para pelaku usaha berbasis e-commerce saat ini juga perlu untuk menyadari dan menaruh perhatian pada kesan-kesan yang sekiranya timbul di masyarakat atas pesan yang disampaikan oleh para pelaku usaha sendiri atas usahanya. Hal tersebut dikarenakan pada network environment saat ini, online word-of-mouth atau electronic word-of-mouth merupakan refleksi dari hasil evaluasi konsumen yang sebenar-benarnya (Xiaofen \& Yiling, 2009), sehingga sangat penting bagi para pelaku usaha untuk membangun citra atau reputasi yang baik atas usaha yang akan atau tengah dijalankannya.

\section{Simpulan}

Berdasarkan hasil penelitian, maka dapat ditarik kesimpulan bahwa variabel persepsi terhadap electronic service quality dan e-WOM masing-masing memiliki peran terhadap intensi pembelian ulang melalui e-commerce. Artinya, persepsi seseorang atas electronic service quality memiliki peran dalam memengaruhi atau menguatkan intensi konsumen untuk melakukan pembelian ulang melalui e-commerce. Begitu pula bahwa adanya informasiinformasi yang beredar melalui e-WOM turut berperan dalam memengaruhi atau menguatkan intensi konsumen dalam melakukan pembelian ulang suatu produk melalui $e$ commerce. Selain itu, seluruh goodness-of-fit index menunjukkan hasil evaluasi fit. Artinya, model memang menunjukkan bahwa data empiris yang diperoleh pada penelitian sesuai dengan model teoritik yang dibangun.

Terkait kelemahan penelitian ada beberapa saran yang dapat diajukan untuk peneliti selanjutnya yaitu, pertama mempertimbangkan penambahan jumlah sample pada beberapa area di kategori jenis kelamin, usia, tingkat pendidikan dan daerah tempat tinggal agar lebih bervariasi serta dapat memperkecil area atau cakupan penelitian. Misal, hanya memfokuskan penelitian pada area tertentu atau satu provinsi saja atau memfokuskan pada salah satu produk maupun toko daring dengan karakteristik tertentu. Kedua, terkait banyaknya item yang gugur saat uji coba pada skala electronic word-of-mouth (e-WOM), maka perlu dilakukan analisis ulang pada alat ukur ini. Analisis ulang dilakukan untuk memastikan item-item dianggap sudah cukup mampu atau tidak mengungkap setiap aspek dari variabel electronic word-of-mouth (eWOM) dan dapat mengukur variabel yang di teliti.

\section{Referensi}

Ajzen, I. (2005). Attitudes, personality and behavior (second edition). Open University Press.

Constantinides, E., \& Holleschovsky, N. I. (2016). Impact of online product reviews on purchasing decisions. WEBIST 2016 - Proceedings of the 12th International Conference on Web Information Systems and Technologies. https://doi.org/ 10.5220/0005861002710278

Dhanapal, S., Vashu, D., \& Subramaniam, T. (2015). Perceptions on the challenges of online purchasing: A study from "baby boomers", generation " $\mathrm{X}$ " and generation " $\mathrm{Y}$ " point of views. Contaduria y Administracion, 60(1), 107-132. https: //doi.org/10.1016/j.cya.2015.08.003

Dodds, W. B., Monroe, K. B., \& Grewal, D. (1991). Effects of price, brand, and store information on buyers' product evaluations. Journal of Marketing Research, 28(3), 307-319. https://doi.org/10.2307/3172866

Febriani, D., Endah, M., \& Prihatsanti, U. (2011). Hubungan antara persepsi terhadap word of mouth (wom) dengan intensi membeli makanan vegetarian pada mahasiswa Fakultas Psikologi Universitas Diponegoro. Jurnal Psikologi Undip, 10(2), 173-183. https://doi.org/10.14710/jpu.10.2. 173-183

Ghozali, I. (2017). Model persamaan struktural konsep dan aplikasi dengan program AMOS 24.0 update bayesian SEM (edisi 7). Universitas Diponegoro.

Golob, T. F. (2003). Structural equation modeling for travel behavior research. Transportation Research Part B: Methodological, 37(1), 1-25. https://doi.org/10.1016/S01912615(01)00046-7

Goyette, I., Ricard, L., Bergeron, J., \& Marticotte, F. (2010). E-WOM scale: Word-of-mouth measurement scale for e-services context. Canadian Journal of Administrative Sciences, 27(1), 5-23. https://doi.org/10.1002/cjas.129

Grewal, D., Monroe, K. B., \& Krishnan, R. (1998). The effects of price-comparison advertising on buyers' perceptions of acquisition value, transaction value, and behavioral intentions. Journal of Marketing, 62(2), 46-59. https://doi. org/10.2307/1252160

Putri, L. H. (2016). Faktor-Faktor yang mempengaruhi minat pembelian ulang konsumen terhadap produk naget delicy. PERFORMA: Jurnal Manajemen Dan Start-Up Bisnis, 1(2), 162-170.

Indriani, A., \& Nurcaya, I. (2015). Pengaruh kualitas pelayanan terhadap word of mouth yang dimediasi oleh kepercayaan pelanggan pada pt. auto bagus rent a car denpasar. E-Jurnal Manajemen Universitas Udayana, 4(5), 1301-1321. 
Joesyiana, K. (2018). Pengaruh word of mouth terhadap keputusan pembelian konsumen pada media online shop shopee di pekanbaru. Valuta, 4(1), 71-85.

Lee, G. G., \& Lin, H. F. (2005). Customer perceptions of eservice quality in online shopping. International Journal of Retail and Distribution Management, 33(2), 161-176. https: //doi.org/10.1108/09590550510581485

Lim, Y. M., Yap, C. S., \& Lau, T. C. (2010). Online search and buying behaviour: Malaysian experience. Canadian Social Science, 6(4), 154-166.

Mittal, A., \& Jhamb, D. (2016). Determinants of shopping mall attractiveness: The Indian context. Procedia Economics and Finance, 37, 386-390. https://doi.org/10.1016/s22125671(16)30141-1

Mo, Z., Li, Y., \& Fan, P. (2015). Effect of online reviews on consumer purchase behavior. Journal of Service Science and Management, 8, 419-424. https://doi.org/10.4236/jssm.2015. 83043

Muda, M., Mohd, R., \& Hassan, S. (2016). Online purchase behavior of generation Y in Malaysia. Procedia Economics and Finance, 37, 292-298. https://doi.org/10.1016/s22125671(16)30127-7

Mujiyana, M., \& Elissa, I. (2013). Analisis faktor-faktor yang mempengaruhi keputusan pembelian via internet pada toko online. Journal Undip: Jurnal Teknik Industri, 8(3), 143-152. https://doi.org/10.12777/jati.8.3.143-152

Palese, B., \& Usai, A. (2018). The relative importance of service quality dimensions in e-commerce experiences. International Journal of Information Management, 40, 132140. https://doi.org/10.1016/j.ijinfomgt.2018.02.001

Peter, P. J., \& Olson, J. C. (2013). Perilaku konsumen dan strategi pemasaran. Salemba Empat.

Prasetijo, R., \& Ihalauw, J.J.O.I. (2005). Perilaku konsumen. Andi.

Putri, C.S. (2016). Pengaruh media sosial terhadap keputusan pembelian konsumen cherie melalui minat beli. Performa: Jurnal Manajemen dan Strart-up bisnis, 1(5). 594-603. Retriefed from https://journal.uc.ac.id/index.php/performa/ article/view/348
Rembon, A., Mananeke, L., \& Gunawan, E. (2017). Pengaruh word of mouth dan kualitas produk terhadap keputusan pembelian pada pt. kangzen kenko indonesia di manado. Jurnal EMBA: Jurnal Riset Ekonomi, Manajemen, Bisnis Dan Akuntansi, 5(3), 4585-4594. https://doi.org/10.35794/ emba.v5i3.18675

Rita, P., Oliveira, T., \& Farisa, A. (2019). The impact of e-service quality and customer satisfaction on customer behavior in online shopping. Heliyon, 5(10), 1-14. https://doi.org/10. 1016/j.heliyon.2019.e02690

Rizqulloh, F., \& Elida, T. (2015). Pengaruh kualitas pelayanan, word of mouth, dan loyalitas pelanggan terhadap niat pembelian kembali pada bukalapak.com. Jurnal Ilmiah Ekonomi Bisnis, 20(2), 113-120. https://doi.org/10.35760/eb

Santoso, S. (2010). Statistik multivariat, konsep dan aplikasi dengan SPSS. PT Elex Media Komputindo.

Setyaningsih, O. (2014). Pengaruh persepsi kualitas pelayanan e-commerce terhadap kepuasan pelanggan, kepercayaan dan loyalitas pada produk fashion. Jurnal Bisnis \& Manajemen, 14(2), 67-80. https://doi.org/10.20961/jbm.v14i2.4126

Sudirman, I. M. S. A. S., \& Suasana, I. G. A. K. G. (2018). Pengaruh kualitas layanan online terhadap kepuasan, komitmen, dan loyalitas nasabah internet banking di kota denpasar. INOBIS: Jurnal Inovasi Bisnis Dan Manajemen Indonesia, 1(4), 473-488. https://doi.org/10.31842/jurnalinobis.v1i4.52

Suryana, P., \& Dasuki, E. S. (2013). Analisis faktor yang mempengaruhi keputusan pembelian dan implikasinya pada minat beli ulang. TRIKONOMIKA, 12(2), 190-200. https: //doi.org/10.23969/trikonomika.v12i2.479

Xiaofen, J., \& Yiling, Z. (2009). The impacts of online wordof-mouth on consumer's buying intention on apparel: An empirical study. Proceedings of the 2009 International Symposium on Web Information Systems and Applications (WISA'09), 24-28.

Zheng, Y., Yang, X., Liu, Q., Chu, X., Huang, Q., \& Zhou, Z. (2020). Perceived stress and online compulsive buying among women: A moderated mediation model. Computers in Human Behavior, 103, 13-20. 